\title{
MEASUREMENTS OF SOUND ISOLATION BY MULTI-LAYER MATERIALS OR STRUCTURES
}

\section{Piotr DEUSZKIEWICZ}

Warsaw University of Technology, Faculty of Automotive and Construction Machinery Engineering, Institute of machine Design Fundamentals, piotr.deuszkiewicz@pw.edu.pl

Abstract

A sound barrier is a structure or device that reduces the level of airborne sound. The basic tasks of such a construction are to provide acoustic insulation and sound absorption. There are many materials available on the market ready to use as such structures used for soundproofing passenger vehicles, construction machinery, power units, etc. In this case, however, the practical use of ready-made materials for minimizing noise requires the use of barriers more complicated in construction than those made of a single material. Thus, each time it is necessary to adjust acoustic parameters of barrier to the individual characteristics of equipment whose acoustic emission we want to reduce. Tests according to standards of such structures require work- and time-consuming and expensive research, e.g. special rooms are required for do this (reverberation and anechoic chambers), which are not always available. In this paper, the author proposes a comparative measurement using a simplified method, which can be used in industrial conditions or small measurement laboratories.

Keywords: sound barrier, multi-layer materials, sound absorption, noise minimization

\section{POMIARY IZOLACYJNOŚCI AKUSTYCZNEJ MATERIAŁÓW LUB STRUKTUR WIELOWARSTWOWYCH}

Streszczenie

Przegroda dźwiękoizolacyjna jest konstrukcją lub urządzeniem, które zmniejsza poziom dźwięków przenoszonych drogą powietrzną. Podstawowymi zadaniami takiej konstrukcji są zapewnienie izolacji akustycznej oraz pochłanianie dźwięku. $\mathrm{Na}$ rynku dostępnych jest wiele materiałów gotowych do wykorzystania jako tego typu konstrukcje stosowane do wygłuszenia pojazdów pasażerskich, maszyn budowlanych, jednostek napędowych itp. W tym przypadku praktyczne wykorzystanie gotowych materiałów do minimalizacji hałasu wymaga jednak stosowania bardziej skomplikowanych w budowie przegród niż wykonane $\mathrm{z}$ jednego materiału. Tym samym każdorazowo trzeba dopasowywać parametry akustyczne przegrody do indywidualnych cech urządzenia, którego emisję akustyczną chcemy ograniczyć. Badania zgodne z normami takich struktur wymagają praco- i czasochłonnych oraz kosztownych badań, wymagane do tego są specjalne pomieszczenia (komory pogłosowe i bezechowe), którymi nie zawsze dysponujemy. W artykule autor proponuje pomiar porównawczą metodą uproszczoną możliwą do wykorzystania w warunkach przemysłowych czy też małych laboratoriach pomiarowych.

Słowa kluczowe: przegroda akustyczna, materiały wielowarstwowe, absorbcja dźwięku, minimalizacja hałasu

\section{INTRODUCTION}

The problem of minimizing noise and protection against it is one $[1,2]$ of the basic problems of occupational safety, transport and comfort in passenger transport, with which employers, vehicle manufacturers and carriers struggle today. Although noise has been a common phenomenon in the human environment for many years, the level of social acceptance of this phenomenon decreases with each passing year. It is present in practically all modern human environments - we meet it at work, on the way to work, and many times at home and in places of recreation and leisure. It has a negative impact on human health, hinders rest and recovery. It reduces the effectiveness of human work and increases the probability of accidents at work.
Every day we are surrounded by an infinite number of noise sources with very different frequency characteristics of the emitted sound. Current legal regulations are increasingly restrictive of the issue of protection from noise at workplaces, in the home and the outdoor environment. Currently introduced machines and devices, vehicles, newly constructed buildings and communication routes are constructed in such a way as to provide people with acoustic comfort. The problem remains with structures that have been in use for years and do not provide such comfort.

Noise and the vibrations occurring together with it are the cause of systematic degradation of the natural environment, deteriorating its quality, sometimes to the extent that significant areas of the biosphere cannot perform their function. The 
influence of noise and vibrations on health and on all human activities is equally harmful. Particularly troublesome, although it is often due to insufficient public awareness, is noise in means of public transport. The rolling stock in use today is often manufactured in years when the problem of environmental noise pollution was not taken into account at all during the construction process of these vehicles [3]. This is particularly true of rail vehicles, which have a life span of tens of years.

As a result of the change in awareness of noise pollution and its effects, both governmental agents and users (passengers) have changed the requirements as to the quality of protection against these factors in currently used vehicles [4-8]. While in the case of urban transport (buses, trams) it is relatively inexpensive to retire vehicles that do not meet current standards and replace them with new ones, in the case of rolling stock this is often not justified for economic reasons. Rolling stock undergoes a number of inspections and repairs during its life to revitalize it. One of them is the socalled main repair, which consists practically of taking the whole vehicle ( railway carriage) into its component parts and building it from scratch. In this case, the passenger space is reconstructed completely from scratch on the existing frame of the old vehicle. If the chassis and load-bearing elements of the wagon are not modified, the passenger space can be built with the new requirements of protection against noise and vibration hazards.

Such specifics of the main repair allow to use the existing sound-absorbing-insulating panels for the reconstruction of the carriage. On the surface, this problem seems easy to solve, just use ready-made products with known acoustic properties and the problem is solved. In practice, however, this approach fails completely. Most railroad carriages are (were) produced in short series or even as oneoff products. Therefore in a train each car can have different characteristics of the sound emitted (propagated by the construction). So in order to provide the same level of vibration and noise reduction in each car, the problem has to be approached individually. Another problem is that the characteristics of the emitted sound have its source both in the installed equipment, supporting construction as well as the noise generated by the external air flow and also internal (air conditioning). This makes it necessary to use multilayer panels with adapted soundproofing characteristics.

Recommended methods for testing and determining the characteristics of such materials are costly, as they require specially prepared laboratory rooms (system of reverberation chambers), material samples of relatively large area $(\sim 10 \mathrm{~m} 2)$ and time consuming. This is a serious problem when it is necessary to test dozens of combinations of different soundproofing panels. The author of this paper decided to carry out a comparative experiment which does not give any objective information about acoustic insulation of the tested structures but allows to choose the best one. The research method is relatively simple in execution, does not require specialised rooms and the necessity to involve more than two workers in the measurements and analyses. It allowed for quick testing of many samples with relatively small area (low cost of preparing the samples for testing) and at the same time it gave repeatable and reliable results in a short time. An additional assumption was the possibility of moving the test stand depending on the needs to use it in different locations [9], so that specialist transport was not necessary.

\section{GENERAL TEST METHODOLOGY}

Acoustic protection of spaces intended for human presence and work as well as vehicles is a very broad subject and it is described many times in scientific and technical literature. Analogically, the method of determining acoustic insulation of rooms is widely described in literature [10-12]. Measurement procedures of acoustic insulation of building walls, rooms and soundproofing materials are developed by laboratories dealing with widely understood acoustics and are based on recommendations of European standards series EN ISO 140. These standards take into account the size of partition, acoustic characteristics of rooms as well as the influence of lateral transmission on the decrease of acoustic insulation by measuring vibrations of construction elements. These standards, however, do not address in detail the issue of acoustic protection of passenger compartment in public transport under conditions of limited possibility to use all available materials, primarily for safety reasons (e.g. fire protection) and for structural reasons. While in construction acoustics the supporting elements (walls) are usually independent structures on which soundproof panels are laid, in case of road or rail vehicles the soundproof materials are often also structural elements. The mentioned standards determine only the methods of determining acoustic insulation of building partitions such as ceilings, walls, windows, doors etc.

European (and world) scientific and technical literature deals extensively with subjects connected with limiting spread of acoustic or vibration energy coming from e.g. machines, industrial plants, road traffic etc. These problems include the construction of cabins, soundproof enclosures used to protect personnel working in industrial plants against the impact of noise from equipment, the construction of acoustic screens and how to protect the environment against adverse effects of noise. Only a few papers deal with the subject of complex vibration and noise protection systems that can be used in the construction of, for example, passenger compartments in vehicles. In most cases, the manufacturers of such vehicles conceal their knowledge behind a veil of secrecy and treat it as confidential data. 
While the subject of portable soundproof enclosures, which can be used to conduct experimental studies of various materials, has been discussed by various authors [13-15], both in Poland and Europe there are no uniform guidelines for the construction and quality assessment of such rooms. There are also no measurement procedures developed to assess the effectiveness of noise and vibration damping, and thus the acoustic (vibroacoustic) safety of multilayer materials intended for the construction of car plating. In most cases, such assessment is made on the basis of measurements of acoustic insulation from air sounds in accordance with the guidelines contained in European standards. However, this method does not allow for a quick assessment of acoustic efficiency of complex structures.
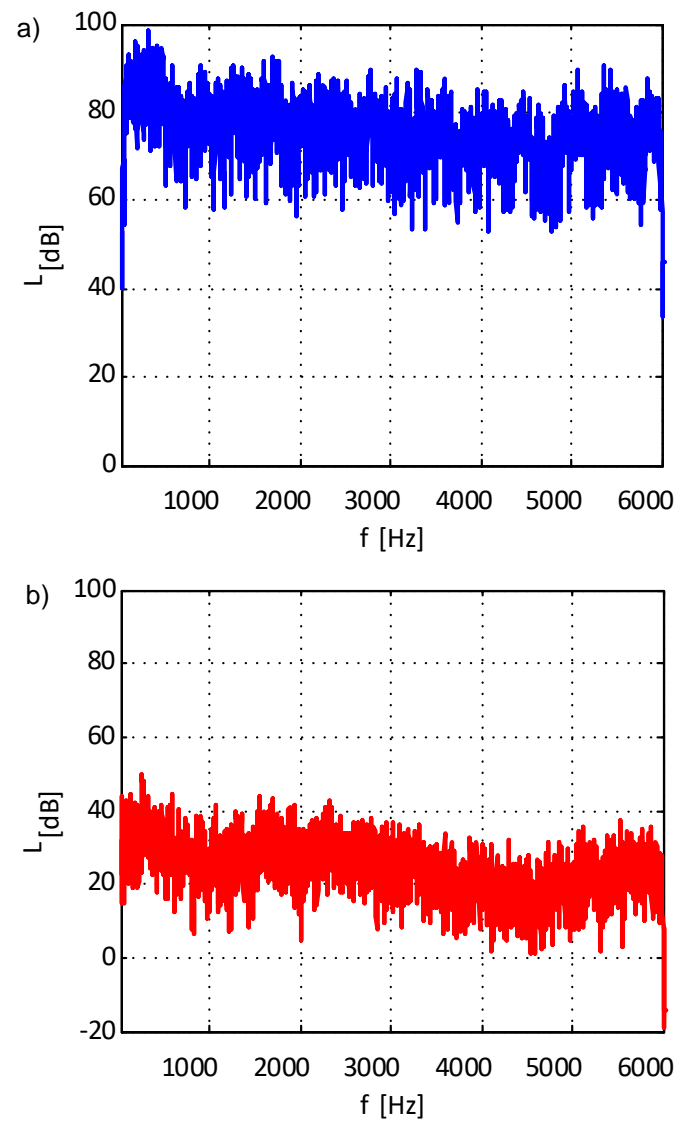

Fig. 1. Acoustic isolation of the panels used to build the reverberation chamber: a) signal spectrum of the sound source - white noise, b) signal spectrum behind the barrier

Without the development of procedures and measurement methodology taking into account the specific requirements for this type of measurements it is difficult to determine whether a combination of sound insulating materials will meet its purpose [1619]. Preliminary results of such tests presented in this paper should enable such assessment and will allow to determine what steps should be taken in order to test acoustic effectiveness giving unambiguous and repeatable results [20].
The task thus set before the author forced him to prioritize the developed research methodology. As the first and determining the feasibility of subsequent postulates, it was decided to discuss the problem of building a portable test stand. The author's previous research work included the construction of a portable sound-isolation chamber, which made it relatively easy to solve the problem. The reverberation chamber, which according to the standards is a required broadcasting room with a sound source placed in it and in whose wall we place the tested sample, was replaced by a chamber made of carbon composite panels. These panels have an internal structure in the form of a sandwich structure (polyurethane foam and mini-gussets) and provide acoustic isolation of over $45 \mathrm{~dB}$ in the $63 \div 6000 \mathrm{~Hz}$ band (Figure 1). The design of the chamber is to ensure a uniform distribution of sound pressure throughout its volume (Figure 2).

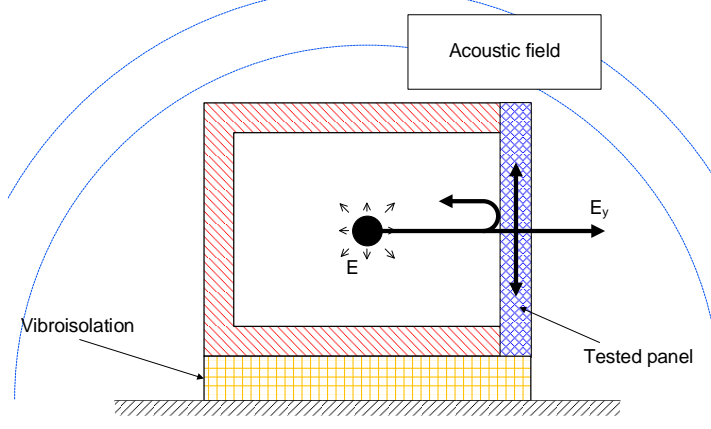

Fig. 2. The ideal insulated echoic room

After selecting the material, the chamber was made as a cube of internal volume of about $1 \mathrm{~m}^{3}$. Internal walls of the chamber are inclined by about $2 \div 4$ angular degrees in relation to the vertical in order to prevent standing waves. In order to ensure acoustic tightness, the connections of the chamber walls are made by overlapping. When unfolded, the chamber fits easily into the trunk of an estate car. A visual representation of the chamber design with an omnidirectional sound source is shown in Figure 3. The maximum sample size measured in such a chamber is approximately $1 \mathrm{~m}^{2}$.

Bruel \& Kjaer measuring and analysis equipment consisting of a 3160-A-42 analyser and PULSE software was used to conduct the tests. The free field microphones BK 4189-A-021 with a nominal sensitivity of $50 \mathrm{mV} / \mathrm{Pa}$ were used for the measurements.

All measurement channels were calibrated with acoustic standard BK 4231 complying with class 1 standards of IEC60942 (2003) and class LS and ANSI S 1.40-1984.

The test signal in the form of broadband noise (white noise and pink noise) was generated using a Bruel\&Kjaer 2734 generator and a BK 4292-L omnidirectional sound source.

Octave spectra were calculated with BK Connect analysis software using octave filters that met the standards: IEC 61260-1:2014 Class 1, IEC 1260- 
1995 Class 1, IEC 225-1996, ANSI S1.11-2004 Class 1, ANSI S1.11-1986 Order 7 Type 1-D, ANSI S1.11-1966 Class 1 Type E, DIN 45651 (1964-01).

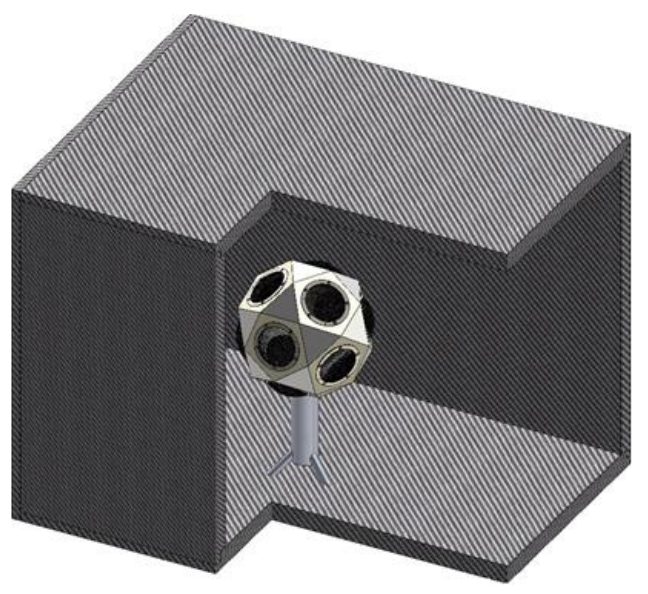

Fig. 3. Visualization of echoic chamber project

\section{MEASUREMENT RESULTS}

As mentioned in Chapter 2, the test acoustic signal was generated using a white and pink noise generator and a BK 4292 omnidirectional sound source. The two measurement microphones were 30 $\mathrm{cm}$ from the outer side of the baffle and $10 \mathrm{~cm}$ from the inner side. They measure the signal in the neighbourhood of the screen to infer its effectiveness.

During testing, random noise excitation was generated in normalized octave bands (so-called pink noise) from $8 \mathrm{~Hz}$ to $8 \mathrm{kHz}$ and white noise from $8 \mathrm{~Hz}$ to $6.4 \mathrm{kHz}$. The difference between the measured sound pressure level for an empty measurement window and after sample insertion illustrates the effectiveness of the tested screen.

Time courses of $60 \mathrm{~s}$ length were recorded during the measurements and then octave averaged spectra were calculated on their basis. The results of the measurements are presented in the form of level difference for an empty measurement window and a window with barrier, as well as the level difference before and after the barrier.

The test specimens consisted of a combination of the following materials: $1 \mathrm{~mm}$ (1) and $1.3 \mathrm{~mm}$ (3) thick aluminium sheet, $45 \mathrm{~mm}$ thick cork layer (2), $2 \mathrm{~mm}$ Temafix mat (4), $20 \mathrm{~mm}$ Whisper FR polyethylene foam (5), and $0.5 \mathrm{~mm}$ galvanized sheet (6). The material designations in Figure 4 are given in brackets.

The TEMAFIX SD soundproofing board is certified in accordance with the requirements of the standard: EN ISO 455-2+A1:2015-12 "Railway applications - Fire protection in railroad vehicles Part 2: Requirements for materials and components with regard to fire performance".

It has excellent soundproofing properties and in this respect meets the requirements of EN ISO 7171. The main application of TEMAFIX SD soundproofing board is soundproofing and fire protection in rail vehicles. It is used in the vehicle floor and walls. Due to the required certification it is designed for railroad applications, but can be used wherever non-flammable material with good soundproofing properties is required. The sealing boards are available as standard in $1500 \times 1500 \mathrm{~mm}$ formats - in thicknesses from $0.5 \mathrm{~mm}$ to $5.0 \mathrm{~mm}$.
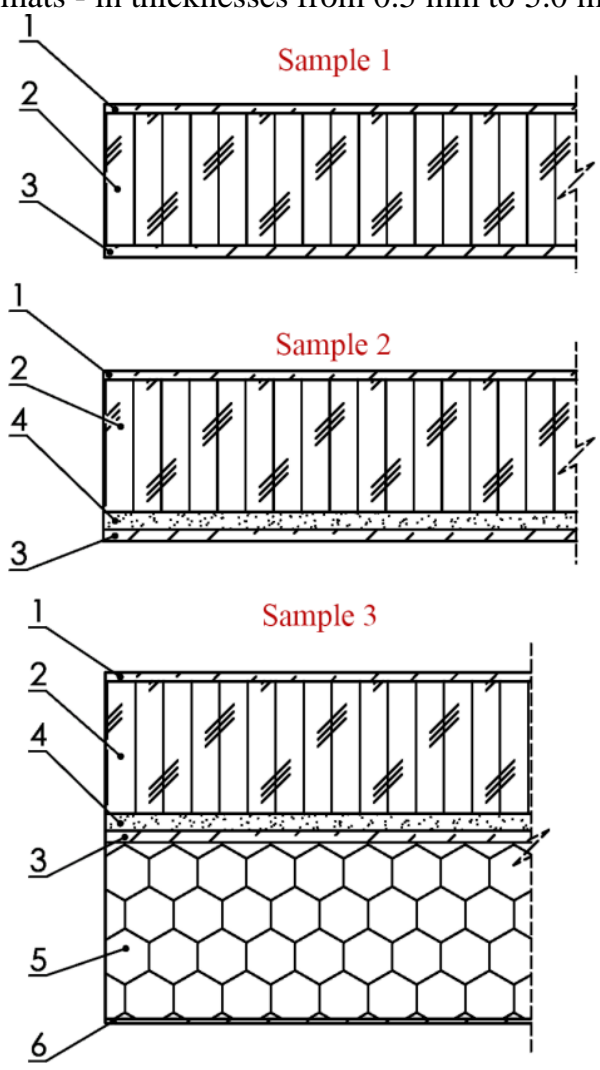

Fig. 4. Examples of test samples

Whisper FR is an non-crosslinked closed-cell polyethylene foam, whose rather large cells have been opened during the production process. The result is a lightweight material with excellent sound absorption. The foam is fireproof-certified and tested for a variety of applications in transportation, public transport, automotive, appliances, electronics and construction. Due to its mechanical strength, Whisper FR laminated foam can be installed as a self-supporting panels.

Tables 1 and 2 show the difference in total sound level for octaves $8 \mathrm{~Hz} \div 8 \mathrm{kHz}$ for measurements without barrier and with barrier in white and pink noise excitation. Tables 3 and 4 show the difference in total sound level for octaves $8 \mathrm{~Hz} \div 8 \mathrm{kHz}$ for measurements with the barrier inside the reverberation chamber and behind the barrier with white and pink noise excitation.

The next figures $5 \div 12$ show the difference in octave band levels for the acoustic signal measured without and with the barrier inserted for Sample 3 with exciting by white and pink noise. All measurements were performed for 2 barrier settings: obverse - side with aluminium sheet (1) outside the 
reverberation chamber, reverse - side with aluminium sheet (1) inside the reverberation chamber.

Table 1. Difference in total sound level between the measurement without a barrier and with a barrier - white noise excitation

\begin{tabular}{lc}
\hline Test sample & Level difference $[\mathrm{dB}]$ \\
\hline Sample 1 & 18.7 \\
\hline Sample 1 reverse & 18.6 \\
\hline Sample 2 & 18.8 \\
\hline Sample 2 reverse & 18.6 \\
\hline Sample 3 & 20.0 \\
\hline Sample 3 reverse & 21.0 \\
\hline
\end{tabular}

Table 2. Difference in total sound level between the measurement without a barrier and with a barrier - pink noise excitation

\begin{tabular}{lc}
\hline Test Sample & Level difference $[\mathrm{dB}]$ \\
\hline Sample 1 & 15.8 \\
\hline Sample 1 reverse & 16.1 \\
\hline Sample 2 & 16.0 \\
\hline Sample 2 reverse & 16.7 \\
\hline Sample 3 & 15.9 \\
\hline Sample 3 reverse & 17.5 \\
\hline
\end{tabular}

Table 3. Difference in total sound level between inside reverberation chamber and behind barrier - white

\begin{tabular}{lc} 
& noise excitation \\
\hline Test Sample & Level difference $[\mathrm{dB}]$ \\
\hline Sample 1 & 27.8 \\
\hline Sample 1 reverse & 27.8 \\
\hline Sample 2 & 28.0 \\
\hline Sample 2 reverse & 27.8 \\
\hline Sample 3 & 28.9 \\
\hline Sample 3 reverse & 30.0 \\
\hline
\end{tabular}

Table 4. Difference in total sound level between inside reverberation chamber and behind barrier - pink noise excitation

\begin{tabular}{lc}
\hline Test Sample & Level difference [dB] \\
\hline Sample 1 & 25.9 \\
\hline Sample 1 reverse & 25.9 \\
\hline Sample 2 & 26.4 \\
\hline Sample 2 reverse & 26.7 \\
\hline Sample 3 & 26.4 \\
\hline Sample 3 reverse & 27.6 \\
\hline
\end{tabular}

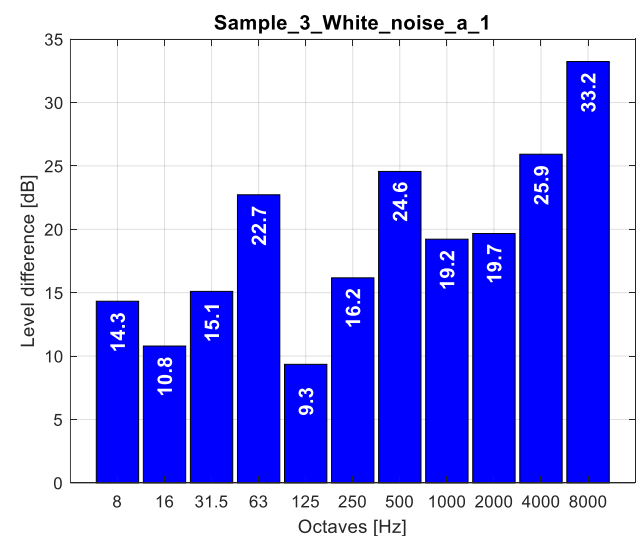

Fig. 5. Example of measurement result - Sample 3 obverse, white noise excitation, level difference without a barrier and with a barrier

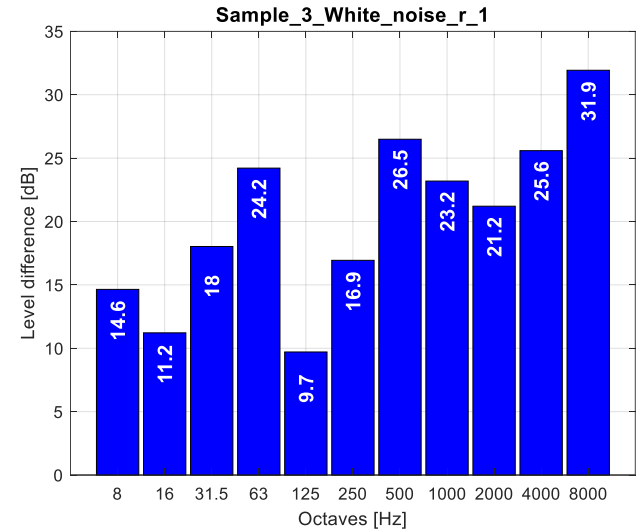

Fig. 6. Example of measurement result - Sample 3 reverse, white noise excitation, level difference without a barrier and with a barrier

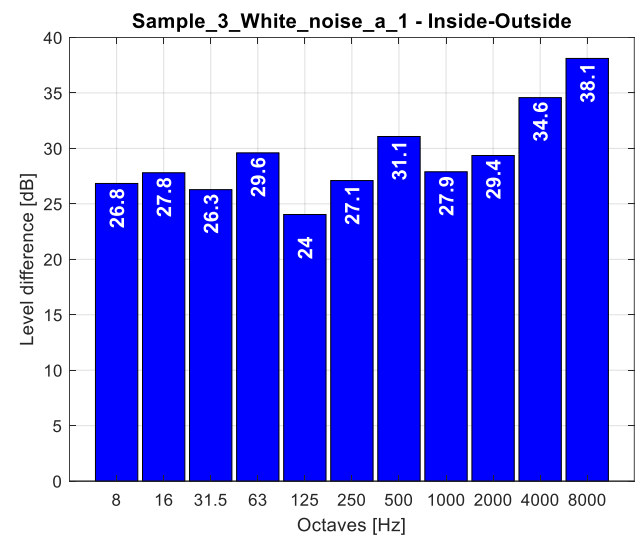

Fig. 7. Example of measurement result - Sample 3 obverse, white noise excitation, level difference between inside reverberation chamber and behind barrier

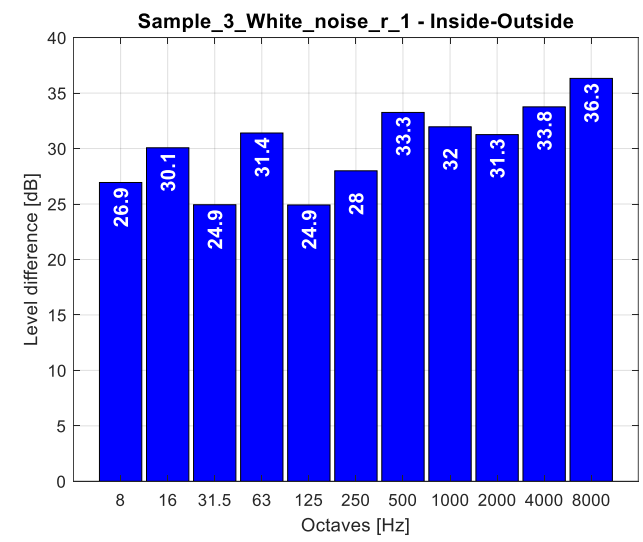

Fig. 8. Example of measurement result - Sample 3 reverse, white noise excitation, level difference between inside reverberation chamber and behind barrier

The results obtained in measurements with a microphone located behind the screen reflect the isolation of the tested sample (the greater the drop in sound pressure level, the more effective the baffle).

The increase of the sound level inside the anechoic chamber after inserting the baffle in front of the screen results from the reflection of the 
acoustic wave, so it is an illustration of the absorbing properties of the material.

The applied testing method allows comparing the effectiveness of sample elements as acoustic barriers limiting the sound propagation (acoustic isolation) and usefulness in application for construction of sound absorbing structures.

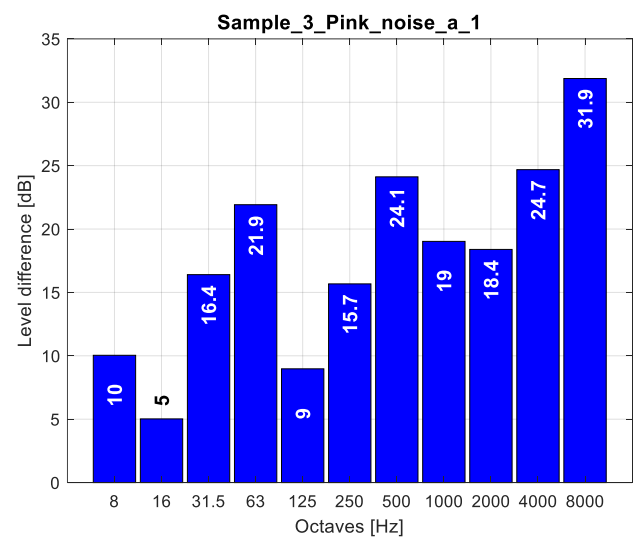

Fig. 9. Example of measurement result - Sample 3 obverse, pink noise excitation, level difference without a barrier and with a barrier

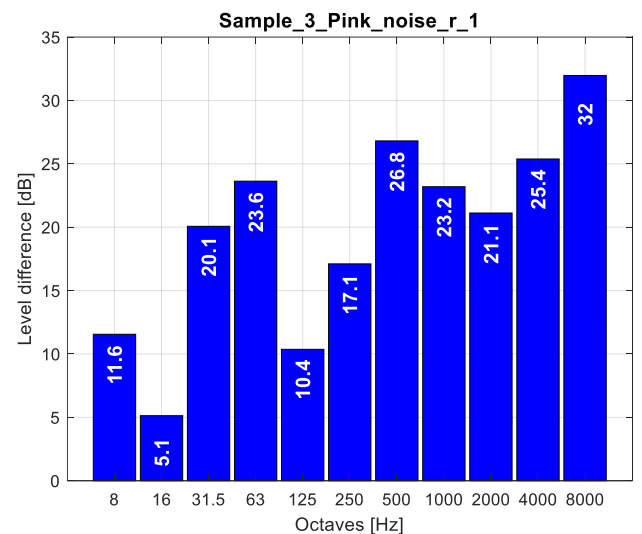

Fig. 10. Example of measurement result - Sample 3 reverse, pink noise excitation, level difference without a barrier and with a barrier

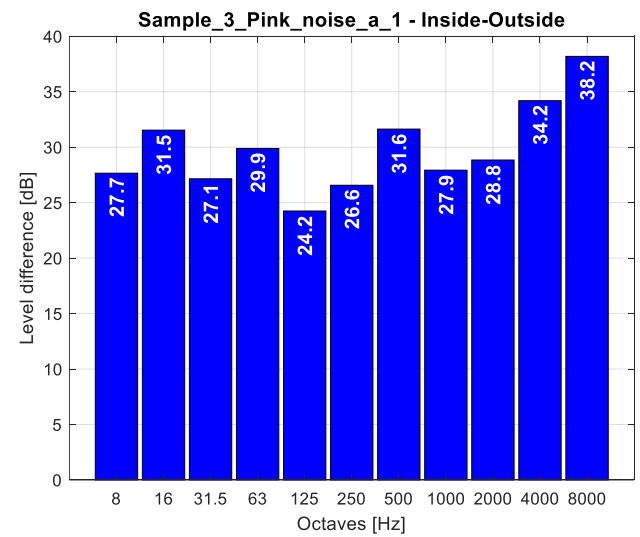

Fig. 11. Example of measurement result - Sample 3 obverse, pink noise excitation, level difference between inside reverberation chamber and behind barrier

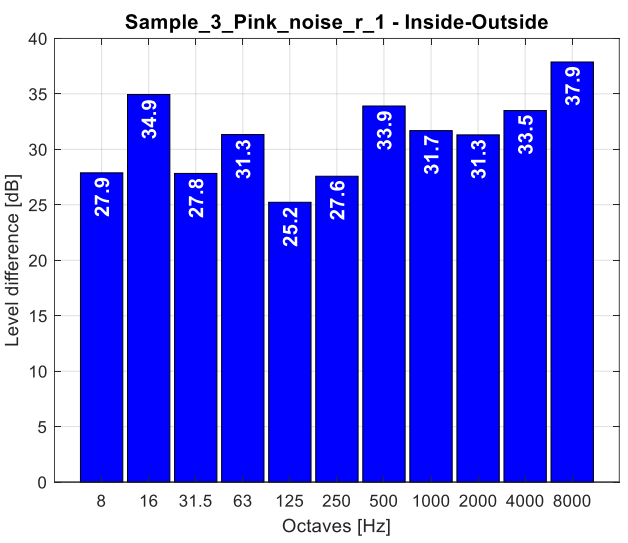

Fig. 12. Example of measurement result - Sample 3 reverse, pink noise excitation, level difference between inside reverberation chamber and behind barrier

\section{CONCLUSIONS}

In spite of the fact that the results obtained in the research are of comparative nature, it can be concluded from them which of the tested samples has higher acoustic effectiveness.

Comparison of test results allows us to conclude that the efficiency of lowering the sound pressure level behind the tested samples in the $8 \mathrm{~Hz} \div 8 \mathrm{kHz}$ band is the best in the case of a three-layer board with Temafix inserts and an additional layer of Whisper FR material (sample No. 3). However, for frequencies up to $1 \mathrm{kHz}$ the addition of a Whisper FR layer does not increase the acoustic efficiency.

The choice of the right material for a sound insulating barrier requires knowledge of the frequency structure of the sound source. Based on the results of this study, we cannot exclude the need to modify the construction of sound insulating panels to achieve a satisfactory minimization of the sound source noise.

\section{REFERENCES}

1. Crocker MJ, Arenas JP. Engineering acoustics: noise and vibration control, $1^{\text {st }}$ edition, John Wiley \& Sons, Inc., 2021.

2. Dąbrowski Z, Dziurdź J. Simultaneous analysis of vibrations and noise in the task of minimizing vibroacoustic activity of machines. Archives of Acoustics, 2016, 41(2). https://doi.org/10.1515/aoa2016-0030

3. Jeong D, Choi HS, Choi YJ, Jeong W. Measuring acoustic roughness of a longitudinal railhead profile using a multi-sensor integration technique. Sensors (Switzerland). 2019;19(7). https://doi.org/10.3390/s19071610

4. Department of Transport. Calculation of Road Traffic Noise. Applied Acoustics, 1988;21.

5. Yaitskov I, Chukarin A. The efficiency of the noise reduction levels of the locomotives and diesel locomotives. Akustika, 2019;32. https://doi.org/10.36336/akustika20193292

6. Dudkin EP, Andreeva LA, Sultanov NN. Methods of noise and vibration protection on urban rail transport. Procedia Engineering, 2017;189. 
https://doi.org/10.1016/j.proeng.2017.05.129

7. Ďungel J, Zvolenský P, Grenčík J, Leštinský L, Krivda J. Localization of increased noise at operating speed of a passenger wagon. Sustainability (Switzerland), 2021; 13(2). https://doi.org/10.3390/su13020453

8. Hegewald J, Schubert M, Freiberg A, Starke KR, Augustin F, Riedel-Heller SG, Zeeb H, Seidler A. Traffic noise and mental health: A systematic review and meta-analysis. International Journal of Environmental Research and Public Health, 2020; 17. https://doi.org/10.3390/ijerph17176175

9. Górnicka D. Klekot G. Michalik M. Examinations of acoustic signal of patients having snoring problem, Journal of Vibroengineering, 2017;19(7). https://doi.org/10.21595/jve.2017.19274.

10. Yang Y, Li B, Chen Z, Sui N, Chen Z, Xu T, Li Y, Fu R, Jing Y. Sound insulation of multi-layer glassfiber felts: Role of morphology. Textile Research Journal, 2017; 87(3). https://doi.org/10.1177/0040517516629142.

11. Shangguan W, Xiong D, Xie X, Yang S, Zhang Q. Measurement and calculation of the sound absorption and insulation characteristics of vehicle-used multilayered panel materials. Zhendong $\mathrm{Yu}$ Chongji/Journal of Vibration and Shock, 2018; 37(1). https://doi.org/10.13465/j.cnki.jvs.2018.01.036.

12. Natsuki T, Natsuki J. A Theoretical Investigation on Sound Transmission Loss through Multi-walled Plates with Air Space. Asian Journal of Research and Reviews in Physics, 2019. https://doi.org/10.9734/ajr2p/2019/v2i129801.

13. Kosała K. Majkut L. Olszewski R. Flach A. Laboratory tests of the prototype stand to determine the acoustic properties of materials used in noise protection (Polish). Technologie XXI wieku - aktualne problemy i nowe wyzwania. Wydawnictwo Naukowe TYGIEL, 2020:7-20.

14. Kosała K. Majkut L. Olszewski R. Experimental study and prediction of insertion loss of acoustical enclosures. Vibrations in Physical Systems. 2020; 31(2): 2020209: 1-8.

15. Kosała K. . Olszewski R. Majkut L. Flach A. Testing of the acoustic properties of a sound insulating enclosure with single and double-layer walls (Polish) WibroTech 2019: 33.

16. Dissanayake DGK, Weerasinghe DU, Thebuwanage LM, Bandara UAAN. An environmentally friendly sound insulation material from post-industrial textile waste and natural rubber. Journal of Building Engineering, 2021;33.

https://doi.org/10.1016/j.jobe.2020.101606.

17. Zhang X, Hu X, Gong H, Zhang J, Lv Z, Hong W. Experimental study on the impact sound insulation of cross laminated timber and timber-concrete composite floors. Applied Acoustics, 2020;161.

https://doi.org/10.1016/j.apacoust.2019.107173.

18. Nurzyński J. Sound insulation of bulkhead panels. Applied Acoustics, 2021; 179. https://doi.org/10.1016/j.apacoust.2021.108061.

19. Shen H, Yang Y, Wang P, Hong Y, Legrand X, Yang $\mathrm{X}, \mathrm{Wu}$ I. Effect of tufting technique on sound insulation of multi-layer glass woven fabrics. Materials Research Express, 2020; 7(9). https://doi.org/10.1088/2053-1591/abb855

20. de la Prida D, Pedrero A, Navacerrada MÁ, DíazChyla A. Methodology for the subjective evaluation of airborne sound insulation through 2-AC and Thurstonian models. Applied Acoustics, 2020; 157. https://doi.org/10.1016/j.apacoust.2019.107011

ISO Standards:

ISO 11201: Acoustics - Noise Emitted by Machinery and Equipment - Measurement of Emission Sound Pressure Levels at a Work Station and at Other Specified Positions Engineering Method in an Essentially Free

Field over a Reflecting Plane

ISO 11688: Acoustics - Recommended Practice for the Design of Low-Noise Machinery and Equipment

ISO 140: Acoustics - Measurement of Sound Insulation in Buildings and of Building Elements

ISO 1996: Acoustics - Description, Measurement and Assessment of Environmental Noise

ISO 1999: Acoustics - Determination of Occupational Noise Exposure and Estimation of Noise-Induced Hearing Impairment

ISO 226: Acoustics - Preferred Frequencies

ISO 354: Acoustics - Measurement of Sound Absorption in a Reverberation Room

ISO 3741: Acoustics - Determination of Sound Power Levels of Noise Sources Using Sound Pressure Precision Methods for Reverberation Rooms

ISO 3744: Acoustics - Determination of Sound Power Levels of Noise Sources Using Sound Pressure Engineering Method in an Essentially Free Field over a Reflecting Plane

ISO 3745: Acoustics - Determination of Sound Power Levels of Noise Sources Using Sound Pressure Precision Methods for Anechoic and Hemi-anechoic Rooms

ISO 7849: Acoustics - Estimation of Airborne Noise Emitted by Machinery Using Vibration Measurement

ISO 9053: Acoustics - Materials for Acoustical Applications - Determination of Airflow Resistance

ISO 9614: Acoustics - Determination of Sound Power Levels of Noise Sources Using Sound Intensity

\section{Received 2021-09-16}

Accepted 2021-12-06

Available online 2021-12-09

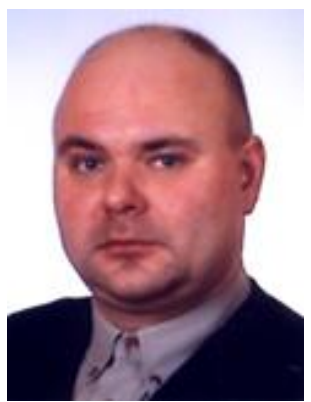

Piotr DEUSZKIEWICZ is employed as an assistant professor at the Warsaw University of Technology, Faculty of Automotive and Construction Machinery Engineering, Institute of Machine Design Fundamentals, Department of Fundamentals of Machine Design and Operation. Currently he is headmaster of Vibroacoustic Laboratory. He received PhD (2012 Warsaw University of Technology, Faculty of Automotive and Construction Machinery Engineering). His research interests are: vibroacoustic phenomena, machinery diagnostic, signal processing, dynamics of drive systems, mechanics of modern composite materials. He is member of head of Polish Society of Technical Diagnostics and a member of The Polish Maintenance Society. 